Review

\title{
Review on Organ Transplantation and Ethical Issues
}

\author{
Rahman MM
}

J Bangladesh Soc Physiol. 2006 Dec;(1):35-39. For author affiliations, see end of text.

\section{Introduction}

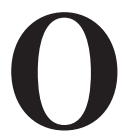

rgan transplantation is by far the best form of treatment for organ failure, Different organs are transplanted now a days in different ways. 1st kidney transplant occurred in 1950 in USA. Heart transplant first done by Christian Barnard of South Africa in 1967. Then other organs were transplanted in different periods.

Every day, people die because there are insufficient tissues available for transplantation ${ }^{1}$.

Ethical issues in health care have increased during the past two decades, primarily in response to rapidly evolving advanced technologies ${ }^{2}$.

Shortage of cadaver organs has prompted transplant centers to seek new sources of Grafts. While living donor left lobe transplantation (Segment II and III) is an established procedure for children, living donor right liver transplantation (Segments V, VI, VII, VIII) which can provide adequate liver mass for an average sized adult patient ${ }^{3}$.

An Urgent and steadily increasing need exists world wide for a greater supply of donor thoracic organs. Xenotransplantation offers the possibility of an unlimited supply of hearts and lungs that could be available electively when required ${ }^{4}$.

\section{Ethical Issues}

Successful transplantation of bone marrow obtained from unrelated donors with their consent. We believe that the ethical issues are overcome by requesting the donation before identification of any patient ${ }^{5}$.

Bone marrow transplantation is one of numerous new medical technologies that have raised

J Bangladesh Soc Physiol. 2006 Dec;(1):35-39 complex legal and ethical issues 6,7. Law has been passed in response to the need to resolve conflicts in judicial opinions ${ }^{7}$.

This article discusses some of the medical, legal and ethical issues in using organs from primates, and anencephalics to transplant to infants who will otherwise die. The use of primates is discouraging on ethical grounds due to scarcity of chimpanzees, the preferred species and to the poor chance of survival. Anencephalic fetuses and newborns are promising sources of organs for pediatric transplants, if ethical and legal considerations are met. An argument is made, based on current practice in management of dying donors that complies with the legal requirement to delay organ removal until after whole brain death. ${ }^{8}$

As the number of children in need of organ transplants increases because of medical advances, so does the demand for organs that can be used in transplantation. In the face of compelling medical need, Prospective donors as well as prospective recipients are subject to strong pressures. Social workers can play a large role in protecting the rights and interests of both groups of youthful clients ${ }^{9}$.

There are grounds for believing therefore that the pressure to subvert good ethical standards in acquiring these organs (that pressure imposed by long waiting lists and a high death rate on those waiting lists) should be avoidable ${ }^{10}$. Is fetal tissue transplantation necessary and beneficial? Are fetal rights violated by the use of fetal tissue in research? Is there a moral danger that the potential of fetal tissue donation will encourage elective abortions? Should pregnant women be 


\section{Review}

allowed to designate specific fetal transplant recipient.

What criteria should be used to select fetal tissue transplant? Whose consent should be required for the use of fetal tissue for transplantation? ${ }^{11}$

During liver transplantation, like for any organ transplantation, the ethical and economical issues must be constantly kept in mind. ${ }^{12,13,14,15}$. A 50 year old man who has a daughter with end stage renal disease has suffered a severe cerebral vascular accident but is neither brain dead nor a candidate for "'non-heart beating" donation. Given his poor prognosis, should the father be able to donate his kidney to the daughter in his compromised condition? ${ }^{16}$

Xenotransplantation or the use of animal cells tissues and organs for humans, has been promoted as an important solution to the worldwide shortage of organs. While scientific studies continue to be done to address problems of rejection and the possibility of animal to human virus transfer, socio-ethical and legal questions have also been raised around, informed consents, life long monitoring, animal welfare and animal rights and appropriate regulatory practices. ${ }^{4,17}$

An analysis of the UNOS database suggests a practice pattern that uses live minor kidney donors in clinical circumstances not endorsed by the recommendations of a recent consensus conference on live organ donation. Live organ donation from a minor should only be considered when there is no other living donor available and all other opportunities for transplantation have been exhausted. ${ }^{18,19,20}$

Basic neuro transplantation research evoked clinical trials of restorative brain surgery. Neural grafting in CNS is irreversible and is therefore not suitable for experimental approaches originally designed for and best suited to drug studies ${ }^{21}$. Neural Fetal tissue transplantation offers promise as a treatment for devastating neurologic conditions such as Parkinson's disease. Two types of issues arise from this procedure: Those associated with the use of fetuses and those associated with the use of neural tissue. ${ }^{22}$
Transplantation and banking of stem cells from cord blood raise different legal and ethical questions. Who owns the cord blood? Does transplantation infringe the physical integrity of the neonate? In addition, if so, who has to give her or his consent? In any case, legal representation by the neonate's guardians has to be guided by the "Welfare of the child". Banking stem cells from cord blood may be private or public. Private banking causes difficulties concerning the right to health care and the issues of justice and equity. Public banking too raises complex legal issues e.g. Protection of potential recipients from life threaten illness at the one hand and the right of the donor to autonomy in disclosing information at the other. ${ }^{23}$

The ethics of embryo stem cell use are complex and deeply personal. ${ }^{24}$

The conclusion is that only patients at risk of dying and with no alternative treatment available should be recruited to xenotransplantation trails in the early phase. $^{25}$

In addition to defensible donor education about risk and benefit, three fundamental Obligations of the centre are identified:

(i) To recognize that it is after ethical to participate in acts of individual risk and sacrifice that are performed to benefit Others:

(ii) Do not deny transplantation without good reason to donors and recipients who apply to the centre; and

(iii) To neutralize, but not overreact to centre self-interest, which stems from the professional benefits of transplantation and the center's desire to help potential transplant recipients. The basic medical facts surrounding donation must be understood by all parties as part of ethical decision-making.

Donor risk can be presented Quantitatively using US Renal Data System data as a baseline. Confirmation of accurate donor Understanding of risks, benefits and alternatives is always a fundamental center Obligation. Donors should not be rejected

J Bangladesh Soc Physiol. 2006 Dec;(1):35-39 


\section{Review}

except for the general reasons. We identify and when these reasons do not seem to apply the decision to deny transplantation should be reconsidered. ${ }^{26}$

Physicians must include both donors and recipients regarding risk, benefits, and allow freely giving consent. ${ }^{27}$

Development of cloning and embryonic stem cell line technologies offers real hope for developing better sources of tissues for transplantation. Research into therapeutic cloning and the development of embryonic stem cell lines is illegal in several states in Australia. There is controversy regarding ethical issues. It is time to review that legislation in order to allow destructive embryo research. $1,28,29,30,31,32$

Questions are posed as to the justification for certain procedures and those pertaining to the Goals of medicine, informed consent and patient quality of life. Other issues include benefits versus risks, patient autonomy and medical paternalism or non-maleficence. ${ }^{3}$

Though xenotransplantation is, important in fulfilling demand of need yet a clinical trial of xenotransplantation should not be undertaking Until experts in Microbiology and the relevant regulatory authorities consider this risk to be minimal. ${ }^{4}$

Ethical principle of utility is enhanced by living donor liver transplantation. Most serious ethical concerns in living donor liver transplantation focus on the risks to the donor and relate to the principle of nonmaleficence "do no harm", Although exact risk remains Uncertain, there is potential for significant donor morbidity and even mortality. Careful consideration must be given to the informed consent, specific criteria for transplant centre and national registry for donors and recipients. 33,34

Careful and Critical evaluation of donor and recipient is required for optional outcome. ${ }^{35}$

Ethical and Psychological aspects related to transplantation from a living donor are complex and need to be carefully evaluated when this treatment is offered to the Patients. ${ }^{36}$

J Bangladesh Soc Physiol. 2006 Dec;(1):35-39
Article summarizes the procedure for cloning human cells to obtain tissues for transplants and comments on the therapeutic possibilities. It discusses the ethical objections raised against the creation of embryos for this purpose. ${ }^{37}$

In uterus stem cell, transplantation represents a new and still experimental therapeutic strategy for diseases related to the hemopoietic system. Ethical considerations based on the use of fetal cells are pointed out and prospective view concerning. ${ }^{38}$

Living relative liver transplantation is a valid alternative to cadaver transplantation especially at a time when the availability of organs cannot meet the requests of long waiting lists. However, the ethical aspect has been widely debated and in order to be acceptable procedure must be comply with three critical points: the need for innovation, an acceptable risk benefit ratio and adequate informed consent. ${ }^{39}$

Article addresses the ethics of selling transplantable organs, I examine and refute the claim that catholic teaching would permit and even encourage on organ market. The acceptance of organ transplantation by church and even it praise of organ donors should not distract us from the quite explicit church teaching that condemn an organ market. ${ }^{40}$

Insofar as organ transplantation itself is concerned one must bear in mind that both the Quran and sunnah neither sanction it nor condemn it. ${ }^{41}$

One Muslim scholar was given opinion against organ transplantation. ${ }^{42}$

On the other hand, Muslim scholars from various parts of the world gave arguments in favor of organ transplantation and that should be recognized as a form of altruistic service to fellow Muslims. ${ }^{43}$

It is true that Islam forbids any act of aggression against human life as well as the body after death. Thus if one were to take an organ out of the dead mans body so as to transplant into another person, it could justifiably be argued to be tantamount to mutilation of the body and violation of the 
Review

sanctity of the corpse. However, it is to be noted here that the Islamic legal system takes the interests of man into consideration. ${ }^{44,45}$

Muslim scholars concern that such sale would be deemed batil. ${ }^{46}$

It is permissible within the shariah to take a part of the human body and transplant it into the same body like removing skin or bone in order to graft it to some other part of the same body. ${ }^{47}$

It is permissible within the shariah to remove the organ from one person and transplantation in into another person's body in order to save the life of that person or to assist in stabilizing the normal functioning of the basic organs of that person. ${ }^{47}$ It is also permissible for a healthy person in the light of the opinion of medical expert of donate on of his/her Kidneys to an ailing relative. ${ }^{48}$

Ii is permissible within shariah to transplantation the organ of an animal, which has been slaughtered according to Islamic rites and/or that of other animals out of necessity. 49

Permissible in shariah to remove an organ from a dead person and transplantation in into a living recipient on the condition that donor was sane and had wished it so. ${ }^{49}$

Surgeon must obtain consent of the next kin before removing organs from cadaver so long as a person is alive his organs should not be removed without his consent. ${ }^{50}$

\section{Conclusion}

Organ transplantation is one of the modern treatments for saving life. Though there is controversy in different religious person yet majority were accepted. It is essential to continue this process but ethical issues must be kept in mind so that harm should be minimum to both donors and recipients.

\section{Acknowledgement}

The author thanks to Bangladesh Medical Research Council, Mohakhali, Dhaka-1212, for financial support.

\section{Author Affiliations}

* Dr Md Mohidur Rahman, Associate Professor of Physiology, Faridpur Medical College, Faridpur, Bangladesh

* for correspondence

\section{References}

1. Savulescu J. The ethics of cloning and creating embryonic stem cells as a source of tissue for transplantation : time to change the law in Australia. Aust N Z J Med. Aug 2000; 30(4): 492-498.

2. Guido G. W. Heart transplantation from an ethical perspective. Crit care Nurs Clin North Am. Mar, 2000; 12(1): 111-119.

3. Mentha G, Morel P, Majno P, Giostra E, Rubbia L, Bednarkiewicz M, Van-Gessel E, Klopfens tein C E, Romand J and Hadengue A. Start of an adult living donor liver transplantation program in Switzerland. Schweiz Med Wochenschr. Aug 26, 2000; 130(34): 1199-1205.

4. Cooper DK, Keogh AM, Brink J, Corris PA, Klepetko W, Pierson RN, Schmoeckel M, Shirakura R, and Warner-stevenson L. Report of the Xenotrans plantation Advisory Committee of the international society for heart and lung. Transplantation: The present status of xenotransplantation and its potential role in the treatment of end-stage cardiac and pulmonary diseases. J heart lung transplant. Dec, 2000; 19(12): $1125-1165$.

5. Rock G, Decary F, McCombie N, Smiley R K, Aye M $\mathrm{T}$ and Huebsch L. Registry of unrelated bone marrow donors. CMAJ. 15 Aug, 1987;137(4): 294-296.

6. Durbin M. Bone marrow transplantation economic, ethical and social issues. pediatrics. Nov. 1988; 82(5):774 -783.

7. Williams TE. Legal issues and ethical dilemmas surrounding bone marrow transplantation in children. Am. J. Pediatr Hematol Oncol. 1984 Spring: 6(1): 83-88.

8. Fletcher, CG, Robertson GA and Hanison MR. Primates and anencephalics as sources for pediatric organ transplants. Medical, Legal and ethical issues. Fetal Ther.1986; 1(2-3): 150-164.

9. Bell CJ. Children as organ donors: Legal rights and ethical issues. Health soc work: 1986 Fall; 11(4): 291-300.

10. Sells RA. Ethical issues in transplantation. Baillieres Clin Gastroenterol. Sept, 1994; 8(3): 465-479.

11. Sanders LM, Giudice L and Raffin TA. Ethics of fetal tissue transplantation. West J Med. Sept, 1993; 159(3): 400-407.

12. Evans R W, Manninen D L, Garrison L P Jr. and Maier A M. Donor availability as the Primary determinant of the future of heart transplantation. JAMA. 11 April, 1986; 255 (14): 1892 -1898.

13. Halkic N, Bally F and Gillet M. Organ transplantation in HIV infected patients. N Engl J Med, Nov 28, 2002; 347 (22): $1801-1803$.

14. Parks W E, Barber R and Painvin G.A Ethical issues in transplantation. Surg Clin North Am. Jun, 1986; 66(3): 633-639.

J Bangladesh Soc Physiol. 2006 Dec;(1):35-39 


\section{Review}

15. Pichlmayr R. Transplantation hepatiques. L experience dehanovre. Chirurgie. 1991; 117(3) : 225-229.

16. Schlessinger S, Crook ED. Black R and Barber H. Ethical issues in transplantation: Living related donation in the setting of severe neurological damage without brain death. Am J Med Sci. Oct, 2002; 324 (4): 232-236.

17. Einsiedel E F and Ross H. Animal spare parts. A Canadian public consultation on Xenotrans plantation. Sci Eng Ethics. Oct, 2002; 8(4): 579-591.

18. Delmonico F L and Harmon WE. The Use of a minor as a live kidney donor. Am J transplant. Apr, 2002; 2(4): 333-336.

19. Hou S. Expanding the kidney donor Pool; ethical and medical considerations. kidney Int. Oct, 2000; 58(4): 1820: 1836.

20. Kher V. End stage renal disease in developing countries. kidney Int. Jul, 2002; 62(1): 350-362.

21. Boer G J and Widner H. Clinical Neurotransplantation: Core assessment protocol rather than sham surgery as control. Brain Res Bull. 30th Sept, 2002; 58(6): 547-553.

22. Nora L M and Mohowald M B. Neural fetal tissue transplants: Old and new issues. Zygon. Dec, 1996; 31(4): 615-633.

23. Seelmann K. Stammzellen aus Nabelschnurblut Rechtliche und rechtsethische Fragen von Transplantation Und Banking. Ther Umsch. Nov, 2002, 59(11): 583-587.

24. Juengst $\mathrm{E}$ and Fossel $\mathrm{M}$. The ethics of embryonic stem cells-now and forever, cells without end. JAMA, Dec 27, 2000; 284(24): 3180-3184

25. Welin S. Starting clinical trials of xenotransplantationreflections on the ethics of the early phase. J Med Ethics. Aug 2000; 26(4): 231- 236.

26. Steiner RW and Gert B. Ethical selection of Living kidney donors. Am J kidney Dis. Oct. 2000; 36(4): 677-686.

27. Anonymous. American college of physician's ethics manual. part 11: Research, other ethics issues. Recommended reading. Ad Hoc committee on medical ethics, American College of Physicians. Ann Intern Med. Aug, 1984; 101(2): 263 -274.

28. Anonymous. Human somatic cell nuclear transfer (cloning). The ethics committee of the American society for Reproductive Medicine. Fertil-steril. nov, 2000; 74(5): 873-876.

29. Krishman A, Molina A and forman S J. Organ transplantation in HIV infected patients. N Engl J Med. Nov 28, 2002; 347(22)1801-1803.

30. Lanza R P, Caplan A L, Silver L M, Cibelli J B, West $\mathrm{M} \mathrm{D}$ and Green $\mathrm{R} \mathrm{M}$. The ethical validity of using nuclear transfer in human transplantation. JAMA. Dec 27, 2000; 284 (24): 3175-3179.

31. Marshall E. Medical ethics. moratorium urged on germ line gene therapy. Science. Sept 22, 2000; 289 (5487): 2023.

J Bangladesh Soc Physiol. 2006 Dec;(1):35-39
32. Mckay R Stem cells-hype and hope. Nature. Jul 27, 2000; 406 (6794): 361-364.

33. Akabayashi A, Nishimori M, Fujita M, and Slingsby BT. Living related liver transplantation: a Japanese experience and development of a checklist for donors' informed consent. Gut. Jan. 2003; 52 (1) : 152.

34. Shapiro RS and Adams M. Ethical issues surrounding adult-to-adult living donor liver transplantation Liver transpl. Nov, 2000; 6 (6 suppl 2): 77-80

35. Marcos A. Right lobe living donor liver transplantation. Liver transplantation. Nov. 2000; 6(6 suppl 2): 59-63.

36. Kamper A L, Lokkegaard $\mathrm{H}$ and Rasmussen $\mathrm{F}$, Nyretrans Plantation med levende donor. Ugeskr Laeger. Nov 27, 2000; 162 (48): 6527-6532.

37. Soutullo D. Clonacion humana no reproductive: Utilizacion de embriones para La obtencion de tejidos para transplantes. Law Hum Genome Rev. Jan-Jun 2000; (12) 213-223.

38. Pschera H. Stem Cell therapy in Utero. J perinat Med. 2000; 28(5): 346-354.

39. Emond $\mathrm{J}$ and De Luca T. Trapiam to di fegato da familiare vivente: Selezione dei riceventie donatori. Minerva chir. Nov, 2000; 55(11): 759-769.

40. Stempsoy WE. Organ markets and human dignity: On selling your body and soul. Christ Bioeth. Aug, 2000; 6(2): 195-204.

41. Ebrahim M F A. Organ transplantation: An Islamic Ethico-legal perspective. FIMA. 2002. 2nd Edition. 69-85.

42. Mufti Muhammad Shafi, Insani A Za'i Ki Paivandkari -Shari'at Islamiyyah ki Roshni main. Karachi: Dar alIsha at, 1967, pp. 29-38.

43. For example see the arguments put forward in favor of organ transplantation by Shaykh Abd al-Rahman alBassam and Shaykh pp. Muhammad Rashid Rida Qabbani, Zira at al-A da al Insaniyyah fi Jism al-Insan in Majallat al Majma al-Fiqhi (1408 AH/1987), pp 1322 and 27-33.

44. Resolutions and Recommendations of the Fourth session of the council of the Islamic Fiqh Academy (1408AH/1988), p. 52.

45. Resolutions and Recommendations of the Fourth session of the Council of the Islamic Fiqh Academy (1408 AH/1988), pp.52-53.

46. Fatwa issued to Islamic Medical Association of South Africa by Dar al-Ifta, Riyadh, Saudi Arabia, p. 14.

47. Qarar al-Majma al-Fiqhi in Majallat al-Majma al-Fiqhi (1408-AH/1987),p. 40.

48. Islamic Fiqh Academy of India- Developing A Religious Law in Modern Times, p. 178.

49. See Qarar al-Majma al Fiqhi in Majallat al Majma al Fiqhi (1408 AH/1987), p. 40.

50. Jesse D Jr. and David S. Organ transplantation : A Proposal for Routine salvaging of cadaver organs. New Egnl. J Med. Aug 22,1968;279(8)413-419. 